\title{
The Effect Of Education Background On The Teachers' Morale In Conducting Their Profession Duties
}

\author{
Bambang Budi Wiyono ${ }^{a}$ \\ ${ }^{a}$ Faculty of Education, Universitas Negeri Malang, Malang, Indonesia \\ Corresponding e-mail: bambang.budi.fip@um.ac.id
}

\begin{abstract}
There are two types of teacher education systems, namely concurrent model and consecutive model. In the concurrent model, the subject matter material is given with the educational material simultaneously, whereas in the consecutive model, the subject matter material is given firstly, then the educational material through teacher profession education. The purpose of this study is to investigate the effect of the education background on teachers' morale in conducting their profession duties. The study used survey research design. The research sample consisted of 89 teachers that graduated from Institute of Teacher Training and Education (concurrent model), and non Institute of Teacher Training and Education (concecutive model), who were taken randomly in Malang city. The data were collected by using questionnaire, and analyzed by using descriptive statistics and $t$ test. The results of the study indicated that there was a significant difference of teachers' morale in conducting their profession duties. The morale of teachers graduated from Institute of Teacher Training and Education were higher than teachers graduated from non the Institute. Based on the result, it can be concluded that concurrent model is more effective than the consecutive model in generating professional teachers. The findings of the study are further discussed in depth based the theory and the previous results.
\end{abstract}

Keywords: teacher's morale, education background, concurrent model, consecutive model, profession duty

\section{INTRODUCTION}

Improving the quality of education is the main factor that determines the success of national development. The history of development in many industrial countries proves that the quality of human resources plays an important role in the development process. To increase the success of national development, it is necessary to improve the human resources. It can only be executed through improving the quality of education.

One of the main reasons that should be done in improving education is to improve work performance of the teachers. Improving the quality of education is basically improving the quality of process and students learning outcomes. Improving the quality of process and students learning outcomes can only be achieved if it is supported by good teachers work performance. Teachers work performance will be good, if it is supported by high work motivation in carrying out the task.

Nowadays when it is examined in the field, the level of teachers professionalism in carrying out the task is still not agree with the expectations. The results of national teachers competence test still not show satisfying results. Additionally, teachers work performance in carrying out the task is still not showing good results. That, clearly has not shown the level of good professionalism of the teachers.

Some efforts to improve teachers profesionalism have been largely undertaken by the government. One of the policies has been implemented to increase the level of teachers educational qualification. All teachers must have a minimum undergraduate education qualification. Teachers educational qualification that is originally diploma II or III, through Law No. 14 of 2005 about Teachers and Lecturers, now teachers must have a minimum undergraduate education qualification or diploma IV. The law is further affirmed in the Government Regulation of 2008 about Teachers which sets teacher competence, rights, and work load. It is expected that the teachers professionalism can be achieved through the improvement of educational qualifications, but it is still not fully achieved.

In addition, the government also develops sustainable teacher development policies. Based on the Decree No. 86 of 1993, the position of teachers has been defined as functional positions, with the levels of positions from pratama teachers (class IIa) 
to the main teacher (class IVe). The regulation was further developed with Permenpan and Bureaucracy Reform number 16 of 2009, about the functional position of teachers and credit score. The promotion is based on the teachers' credit score. Each activity undertaken by the teachers is awarded in accordance with the load of the undertaken activities. With this system, it is expected to encourage teachers to work harder, and ultimately can improve the quality of education.

If it is examined further, teachers qualification can be done through the education before holding a position (pre-service), or after serving as a teacher (in-service education). Education before holding position, broadly, there are two models of teacher education, namely concurrent model and consecutive model. Concurrent model is a model of teacher education, in which the field of study expertise is provided simultaneously with the field of education and teacher training, while the consecutive model is the teacher education model, in which the field of expertise of the field of study is given first, then a new field of educational and teacher training through professional teacher education. Which model is the most effective in preparing teacher candidates still remains a question.

Based on the results research which conducted in elementary school, showed that the level of education influences the teacher work performance, with $r$ value 0.21 , and beta 0.11 [1]. On the other hand, the results of research found that there is no effect of education level on teacher work performance [2]. The results of research further indicated that there is a direct correlation of teacher educational background with work motivation, with coefficient $\mathrm{r} 0,097$, but there is no direct correlation between educational background with teacher work team effectiveness [3]. From the results of this research, it can be underlined that the level of education does not have a strong influence on teacher performance. For that, it is necessary to be studied further. The model of applied education also affects the achieved results.

If it is examined from the side of training position also has not shown optimal results. Development activities or teachers development have been carried out at all levels of education continuously. Even since the implementation of nine years of basic education, teachers training activities are more encouraged again, especially in basic education, it is known as professional teacher training. Through the policy, it is expected that teacher development activities can be implemented effectively, and can improve the teachers professionalism in performing the task. However, based on several reserach results, the goal is still not achieved optimally [4]; [5]; [6]; [7].

Based on that foundation, this research was conducted. This study is aimed to compare the teachers work performance in performing tasks in terms of educational background. Through this research, it is expected to obtain information about the appropriate educational model to produce professional teachers.

\section{METHODS}

This research is aimed at determining the difference of work performance on the teachers in carrying out the task, in terms of educational background. This research did not give treatment, but it revealed from the existing data. Therefore, the research design used in this research is a comparative causal research. So, the data collection, data analysis and conclusion refers to comparative causal research procedures. Based on the target of the research, population in this research is all the teachers of elementary schools in Malang regency. Since it has the large numbers of teachers, by considering the characteristics of the population, sampling is executed. The sample was 89 teachers taken by "random sampling technique".

To obtain research data, this research used two techniques of data collection, namely: questionnaires and documentation. Questionnaires were used to collect data about the teachers work performance in performing the task. Documentation is used to supplement the obtained data through questionnaires, particularly documentative ones, such as documents on teacher characteristics, school characteristics, and so forth.

The research instrument used in this research was developed based on the research variables. Before applying the instruments, the test was conducted to see the level of validity and reliability of research instruments. Tests were conducted on the same target, which were not taken as research samples. The validity of the instrument was tested by item validity test. While the level of reliability of the instrument was tested by the reliability test Alpha Cronbach. The calculations were made by using SPSS computer program.

Based on the results of the instrument analysis, it can be highlighted that each of the instrument items has met the requirements, which is indicated by a significant positive correlation between the items with the total score, with the coefficient $>0.3$. It means that each item measures the same construct. Reliability test results obtained $0.87(>0.7)$. It shows that the instrument used in this research is valid and reliable. 
In accordance with the purpose of research, and by considering the account of existing data, then this research implemented two techniques of data analysis, namely descriptive statistics and analysis of variance. Descriptive statistics was used to describe the teachers work performance in performing the task. Analysis of variance was used to analyze the work performance differences between teachers from the graduate of teacher and pure science.

\section{RESULTS AND DISCUSSION}

Based on the results of the analysis, it can be seen that the average value of teachers work performance from the Institute of Teacher Training and Education in carrying out the task obtained 49.77, while the teachers work performance from the graduate of pure science obtained 45.72 . The value shows the difference, but to know carefully needs to see coefficient of difference that exists. The results of the general difference analysis are presented in Table I.

Table I. Result of Variance Analysis

\begin{tabular}{|l|c|c|c|c|c|}
\hline & $\begin{array}{c}\text { Sum of } \\
\text { Squares }\end{array}$ & Df & $\begin{array}{l}\text { Mean } \\
\text { Square }\end{array}$ & F & Sig. \\
\hline $\begin{array}{l}\text { Between } \\
\text { Groups }\end{array}$ & 235.815 & 1 & $\begin{array}{c}235.81 \\
5\end{array}$ & 3.974 & .049 \\
\hline $\begin{array}{l}\text { Within } \\
\text { Groups }\end{array}$ & 5162.005 & 87 & 59.333 & & \\
\hline Total & 5397.820 & 88 & & & \\
\hline
\end{tabular}

Based on the table presented above, it can be concluded that there is a significant difference on teacher work performance in carrying out the task between the graduate of Institute of Teacher Training and Education (IKIP) and non IKIP (pure science). The teachers' work performance of graduate IKIP is higher than non IKIP. Thus, it can be concluded that the concurrent education model is more effective than the consecutive education model in producing professional teachers. That is, because teachers who graduated from the Institute of Teacher Training and Education (IKIP) in essence reflect concurrent models, and non graduate IKIP reflect the model of consecutive.

Difference of two mean of teachers' morale in carrying out their profession duties can be presented in the form of figure as follow.

The background of Education

The results of this research are in accordance with the results research which showed that there is a difference of self-efficacy of prospective teachers based on its college [8]. Prospective teachers graduate of educational faculty have significantly higher self-efficacy compared to graduate of pure

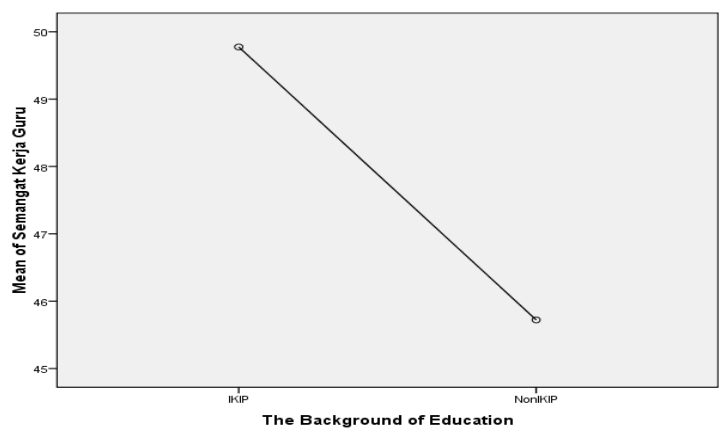

sciences faculty. The results also mentioned that there is a significant relationship between the experience of education with the vision of elementary school teacher [9].

Based on the results of this research, it can be underlined that, in order to prepare candidates of qualified educators and education needs to apply quality pre-service education model. The quality of education, in terms of objectives, content, learning strategies, and evaluation system.

To produce qualified educators and education, the goals and content of education should be vivid. The purpose and content of the education should lead to real competencies that must be mastered by educators or education in accordance with the job description that will be carried. The content of education programs, additionally refers to the objectives to be achieved, also needs to consider the elements of local cultural wisdom (local cultural genius) and positive values of global culture.

There are differences whem it is compared to the several studies in European countries. For example, in England and Scotland, teacher education programs are determined by the central city, so they have same standard of references. However, in Spain and Finland, teacher education programs may differ according to regional characteristics [10]. Teacher education programs in Indonesia, although having the flexibility associated with curriculum content, but teacher education goals and programs tend to be centrally defined.

The purpose of educational institutions that produce prospective teachers need to be associated with the purpose of school which will be taught. For example, the purpose of secondary school education is to lay the groundwork of intelligence, independent living skills, and follow-up education. High school graduates are expected to show good behavior and personality, noble, good behavior and moral, smart, innovative, high work performance, love of the nation, country, homeland, and neighbor. Thus a 
pre-service education program for prospective high school teachers should be provided with these relevant skills. For that, there needs a refinement to the contents of the teacher education curriculum.

The results research indicated that to improve the teachers professionalism, in teacher education programs, it is not only give the provision of professional competence, but also personal competence, self-awareness, responsibility, emotional control, and social ability need to prospective teachers [11]. As a result, there needs a refinement of the existing teacher education curriculum. Character education that in fact is encouraged in school, needed more to be conveyed in teacher pre-service educational institution. Religious values, honesty, discipline, independence, caring, and so on, need to be emphasized in teacher pre-service education.

In addition to improving the goals and content of teacher education, it needs to develop the strategy of education and learning. Learning strategies should be effectively implemented on the basis of an up-todate education by considering other aspects of the dimension. There are certain strategies that need to be applied in educating or instilling character to the students. The strategy refers to the moral development of students (moral cognitive development). One of the learning models that can be applied to educate the character of the students is a strategy of value disclosure with value clarification technique (VCT). Effective guidance models are needs to be given to shape students characteristics. One of the most relevant and widely applied guidance models is through cognitive behavioral therapy (CBT). Thus, it is necessary to develop the side of pedagogy, that needs to be implemented in pre-service teacher education institutions.

Another component of learning strategy, which needs to be developed is the use of learning methods, learning media, and learning resources. The learning experience received by prospective teachers in pre-service education institutions will influence the performance of prospective teachers when they become teachers, because what they have learned and gained like using varied methods, media, and learning resources in the previous education tends to be adopted and applied when they come to be a teacher. Conversely, when the prospective teachers never experience using innovative methods or media, so they will not inspire to apply innovative learning methods. Similarly for the educational program of pre-service education personnel needs to develop the characteristics of the task that is suitable with the tasks that will be implemented.

Beside the objectives, content, and learning strategies, systems of teacher education evaluation also need to be developed in more professional manner. Evaluation is the process of describing, collecting, interpreting, and presenting information for judgment in a decision making in managing and developing teacher education programs. Evaluation is not only aimed at measuring processes or results (outcomes), but also leading to its context, input, and outcomes. The evaluation results are used as the basis for planning the education program (planning decision), organizing the program (structuring decision), implementing the program (implementing decision), and executing follow-up educational teachers program (recycling decision).

Generally, there are four steps that need to be done in carrying out the evaluation of teacher preservice education, which is to set goals, set evaluation strategy, conduct evaluation, process and interpret the evaluation results. There are two types of teacher education program objectives, namely internal goals and external goals. Internal goals are explicitly written in educational programs. While external goals are not expressly written in the program, but they are expected to be achieved as the target of the accompaniment (nurturant effect). The purpose of education and learning becomes a reference in measuring the successful process and results of teacher education.

The success of educational programs is not only determined by the quality of the model that being used, but also the aspects of management. In educating or instilling good behaviour and moral to the students can be realized in the form of learning in the classroom, but it also can be done through the creation of the environment, habituation and culture in daily life.

Based on that explannation, in conducting effective pre-service education program for prospective teachers should be supported by a good education management system. Management education can be viewed from the side of its function and substance. From the side of the function, there are planning, organizing, coordinating, supervising or evaluating. In terms of substance, it includes the field of learning, students, staffs, finance, infrastructure facilities, or relationships with the social community. Education will be more successful, if it is supported by the social community. The results of study showed that public participation on education is still relatively very less [12]. Meanwhile, to form the graduates who are competent and have good characteristics, it needs a support from the social community, especially parents. Therefore, it needs a professional education management in managing teacher pre-service education program. 


\section{CONCLUSION}

Based on the results of this study it can be concluded that there is a significant difference of the teachers' morale who graduated from the Institute of Teacher Training and Education (IKIP) with graduates of non-Institute of Teacher Training and Education (non-IKIP). The morale of teachers who graduated from the IKIP higher than the teachers who graduated from the non-IKIP. That means the concurrent education model is more effective than the consecutive education model in producing professional teachers, because teachers who graduated from the IKIP reflect concurrent models, and non graduated from the IKIP reflect the model of consecutive.

Based on the findings of this study, it is concluded that it had better use the concurrent education model in producing the professional teachers. The content of education need to be provided since the beginning program in teacher education. The purpose of teacher education needs to be instilled early on, as well. Learning strategies also need to provide more early learning practices. Thus, will be able to form a professional teacher. The prospective teachers are not only given knowledge, but also teaching practice, so that it can produce tha professional teachers.

\section{REFERENCES}

[1] B. B. Wiyono, "Faktor-Faktor yang Berpengaruh terhadap Semangat Kerja Guru dalam Melaksanakan Tugas Jabatan di SD," Ilmu Pendidikan, Jurnal Filsafat, Teori dan Praktik Pendidikan, 28 (2), 2001, pp. 131-140.

[2] A. Timan, D. N. Benty, \& Maisyaroh, "Karakteristik Guru, dan Pengaruhnya terhadap Semangat Kerja Guru di Sekolah Dasar Negeri dalam Melaksanakan Tugas," Manajemen Pendidikan, 17 (2), 2004, pp.127-136.

[3] B. B. Wiyono, "Hubungan Struktural TingkatPendidikan, Pengalaman Kerja, dan Usia Guru, dengan Motivasi Kerja dan Keefektifan Kerja Tim Guru Sekolah Dasar," Jurnal Pendidikan Dasar, 10 (1), 2009, pp. 80-91.

[4] F. N. D. Kummerer, \& P. Lynch, "Educational Policy and Planning Project: A Review of Teacher Education Issues in Indonesia," Jakarta: Center for Informatics Office of Educational and Cultural Research and Development, 1990.

[5] A. Suryadi, \& Tilaar, Analisis Kebijakan Pendidikan: Suatu Pengantar. PT. Remadja Rosdakarja, Bandung, 1993.

[6] I. G. A. K. Wardani, "Program Pemberdayaan Guru," Jurnal Ilmu Pendidikan, 6(4), 1998, pp. 289-301.

[7] B. B. Wiyono, \& Maisyaroh, "Pembinaan Kemampuan Mengajar Guru di Sekolah Dasar, dan Pengaruhnya terhadap Kemampuan Mengajar Guru," Jurnal Ilmu Pendidikan, 14 (2), 2007, pp. 128-133.

[8] A. Azar, "In-Service and Pre-Service Secondary Science Teachers' Self-Efficacy Beliefs About Science Teaching," Educational Research and Reviews, 5(4), 2010, pp. 175188.
[9] O. Gurbuzturk, K. Duruhan, \& N. Nihat, "Preservice Teachers' Previous Formal Education Experiences and Visions About Their Future Teaching," Elementary Education Online, 8(3), 2009, pp. 923-934.

[10] A. Mcphee, \& H. Walter, "Teacher Education and Teacher Development: A Comparative Study," Teacher Development: An International Journal Of Teachers' Professional Development, 2(2), 1998, pp. 165-178.

[11] B. Malm, "Toward A New Professionalism: Enhancing Personal and Professional Development in Teacher Education," Journal of Education for Teaching: international Research and Pedagogy, 35(1), 2009, pp. 77-91.

[12] B. B. Wiyono, "Partisipasi Masyarakat terhadap Pelaksanaan Kegiatan Pendidikan," Manajemen Pendidikan, 23 (1), 2010, pp 1-11 